\title{
ASSESSING THE INFLUENCE OF LEADERSHIP ON THE IMPLEMENTATION OF GOOD GOVERNANCE IN A NEW AUTONOMOUS REGION
}

\author{
Marukan Hendrik \\ Student of Doctoral Program Public Administration Department \\ Faculty of Administrative Science, Universitas Brawijaya, Indonesia. \\ Address: Mt.Haryono Street 163, Malang, Indonesia. \\ E-mail: marukan04@gmail.com (Corresponding author)
}

\section{Bambang Supriyono}

(Dr.Bambang Supriyono, MS), Professor in Local Government,

Dean of the Faculty of Administrative

Science, Universitas Brawijaya, Indonesia.

\section{M.R. Khairul Muluk}

(Dr. M.R. Khairul Muluk, M.Si) Associate Professor in Local Governance, Head of Governance Laboratory Faculty of Administrative Science,

Universitas Brawijaya, Indonesia.

\section{Mardiyono Mardiyono}

(Dr. Mardiyono, M.PA), Senior lecturer, Faculty of Administrative Science,

Universitas Brawijaya, Indonesia.

\begin{abstract}
The analysis of any leader's tenure in the public sector is particularly useful for mapping past mistakes and making projections about the future. However, when the analysis is conducted on a leader's tenure in some democratic regions, it can be confusing. It is difficult to measure the performance of the leader due to the asymmetric programs and policies in this region - fully implementation of some programs and policies take longer than the tenure lasts. This study offers an assessment of the influence of leadership toward the implementation of good governance in a new autonomous region - Lamandau - so that any confusion can be avoided. By using a quantitative approach, this study intended to reveal the influence of leadership in the public sector toward good governance implementation in Lamandau city, Indonesia. It examined four independent variables from a leadership aspect: vision (X1), communication (X2), collective purposes (X3), and individual capacity of the leader (X4) toward four dependent variables from good governance: Transparency (Y1), accountability (Y2), independency (Y3), and justice (Y4). Results of a quantitative analysis from a series of empirical data (derived from various variables) have a significant value. The discussion of this study is limited to a historical context of public sector leadership and good governance in Indonesia generally and par-
\end{abstract}


ticularly in Lamandau City, combined with their theoretical foundation. Furthermore, it also offers the future projection of the Lamandau leader based on the analysis of this research. This study could have a significant impact, in particular regarding leadership and good governance in this new autonomous region of Indonesia.

Keywords: leadership; good governance; new autonomous region; Indonesia.

Citation: Hendrik, M., Supriyono, B., Muluk, M.R. K., \& Mardiyono, M. (2018). Assessing the Influence of Leadership on the Implementation of Good Governance in a New Autonomous Region. Public Administration Issues, Special Issue II (electronic edition), pp. 5-23 (in English); DOI: 10.17323/1999-5431-2018-0-6-5-23

\section{Introduction}

Whether it is acknowledged or not, public sector leadership is continuously becoming a particular consideration for the development of every region around the planet (Birney et al., 2010). There are plenty extant literatures explaining this process through various ways such as the simple approach to maximize the particular skills of individual through leader and follower conception or the collective approach that may be applied to strengthening institutional performance (Sotarauta, 2007). The compilation of these studies discussing public sector leadership indicate its important role within government embodiment (Marshment, 2016). Around the literature of public sector leadership, one of fundamental problems aligning this discussion is how the relationship between a leader and the environment in which they find themselves is well-managed (Körösényi et al., 2016; Hay, 2002). The relationship between the leader and the environment creates a particular space enabling them to affect and influence each other (Genovese, 1979; Rossiter, 1948). A great leader needs a critical situation to grow and make self progress, but the critical situation also needs a great leader to solve it (Tucker, 1968). It can be inferred that the challenging situation will become the perfect environment for a great leader to solved while gaining valuable experience for leader at the same time. However, a perilous impact may occur when the leader is incapable of making the environment well-managed, thus he fails to solve the problem (Hay, 2002).

Under this circumstance, an evaluation regarding the leadership quality during the leader's tenure is increasingly essential in order to make appropriate projections for development in the future (Bale, 2015). Recent studies conducted through the investigation of behavioral and cognitive traits have proven a strong correlation with leadership behavior including skill, style and other attributes of capability toward the leader's performance (Folley, 2008; Greenstein, 2009). Furthermore, Vondey (2012) and Rafflo (2013) explain that public sector leadership has become a determining factor toward the success of good governance implementation. Derived from these experiences, assessing the leadership influence would be more precise, particularly when conducted through a public sector leader and their ascendancy.

Some scholars might agree that assessing leadership in public sector is slightly more complex than doing similar in the private sphere. The first reason support- 
ing this statement is that the public sector has multiple orientations. Several works express the orientation of private organizations to be profit, while public organizations are merely service oriented (Mitchell, 2002; Frederickson, Smith, Larimer \& Licari, 2012). However, in taking a more detailed look, the orientation of a public organization may be separated into unrelated fragments such as maximizing public goods, fostering democratic society, maintaining equity or even looking for profit through their state owned enterprises (Steinberg, 2013). The second reason however is closely related to common asymmetric programs and a leader's performance occurring in the public sector.

In a democratic country many regions will apply certain time period to a leader's position in a governmental institution. Within the Indonesian context this period could be five to six years; this period is applied to the tenure of almost all politicians in both local and central government. Under this condition, the public sector leader who has been elected through the ballot system is authorized to carry out their policies for their five or six years tenure (Giyanto, 2012). In fact, some of their programs need even more time to be completely finished, such as gigantic infrastructure developments or any programs dependant on natural processes, such as massive reforestation. Consequently, the next leader as successor will find that those programs will finish under his tenure and he will quantitatively perform better than his predecessor, even though the programs originated through the ideas of his predecessor. Both of these reasons indicate the common difficulties faced by researchers when assessing the influence of leadership in public sector.

Lamandau city, as a case study in this inquiry, was expected to avoid both nuisances above since it is classified as a new autonomous region and has sufficient experience of one mayor who had been elected for two times. This paper tries to assess the influence of public sector leadership in this new autonomous region by using good governance as a yardstick. It concerns public opinion which is represented by the formal power of the leader in the public sector (Marshment, 2016). On this occasion, the leadership does not merely interact with the new autonomous region; its influence on good governance is also measured. Thus, any cohesion among them can be taken and paired with the new autonomous region as it refers to the leader's environment. Although discussions on leadership mainly relate to position, power or structure while good governance is closer to network or collaboration (Denhardt \& Denhardt, 2007), this paper emphasizes the straight hypothesis. It explains that the influence of public sector leadership toward good governance would be examined directly without considering its structure and specific pattern.

\section{Public Sector Leadership: Literature Review}

This section addresses the shaping of the concept of public sector leadership undertaken by this study since there are numerous conflicts among scholars in terms of defining the concept of leadership in the public sphere. These conflicts arise due to the blurred distinctions between public and private organizations which have occurred in recent decades (Steiberg, 2013). In the classical view, pub- 
lic administration, management and organization theory have clearly defined the difference between public and private organization in some circumstances, although the numerous resemblances among them seem difficult to neglect (Khan \& Khandaker, 2016).

Looking back to the early stages, where leadership was in reference to some businessmen's groups in the United States, or before a set of popular books on leadership were published in 1912 (Gill, 2011), it was clearly stated that the soul of effectiveness brought by the conception of leadership originated from the private environment that enables firms to gain more profits (Stone \& Patterson, 2005). The rapid changing of the economy in the United States provoked by the industrial revolution had become the main trigger of technological development and consequently it was followed by the increase in the capacity of human resources. In line with this development, the concept of hierarchy and bureaucracy became widely known by the leader as the main component (Morgan, 1997). Many scholars believe that the context of leadership in the private sector attracted more attention than in public sector because the goals and purposes of the private sector seemed to be clearer than in the public sector where these things are sometimes ambiguous (Steinberg, 2013). In some discussions, people may argue that the nature of leadership's conception belongs to the private sector, and that the context of leadership in the public sector is merely a fraction of that in the private sector (Wart, 2003). A few decades later the most prominent researchers of leadership such as (Ralph Stodgill,1948; MacGregor, 1960; or Bennis \& Nanus, 1985) underlined a leader's behavior and influence as the essential instrument rather than debating its scope.

In 1978 the topic of leadership was opening a new paradigm called transformational leadership. It emphasized the leader's capability to transform his follower, structure, or even stakeholder by his vision, style, influence, and charismatic quality (Wart, 2003). At this point, again, the discussion about the nature of leadership was continuing to increase. The debate about the public and private sectors regarding their differences and similarities adorns the topic in public administration, economics, and politics literature (Boyne, 2002). However, aside from these debates, many scholars in both sectors agreed that the leadership conception is related to something called the influence (Hersey, Blancard, and Johnson, 1996; Lussies and Achua, 2007). Some scientist might call this an influence with other expressions such as persuasion (Gardener, 2010) or motivation (Burns, 2000) but still it refers to the intuitive role of person against people.

The trend in discussion about public sector leadership moves in a same direction as the development of technology. In addition, it seems difficult to neglect that the rapid change of technology has affecting society's behavior to be aware of a leader's behavior (Yankelovich, 1991). A study conducted by Faculty of Administrative Science University of Brawijaya (2012) in a less developed region proved that there is less demand for a society's satisfaction in a leader's performance there than in a developed territory. In the Indonesian context, the awareness of society toward their local leader can vary depending on technological development, local indigenous culture, resource balance or other external factors, although an effort to frame its border is still possible to do. Pramudji 
(1985) in his article argues that the discussion on public sector leadership in Indonesia is limited by its structure including central government, provincial government, local government, district, as well as the village government. While Kaloh (2009) explains from another perspective; he conveys that the discussion of public sector leadership must be highly dependent on the Indonesian governmental structure comprised of executive, legislative, and judiciary. In addition he also divides the kind of public sector leadership according to its position, for instance, political leader, administrative or structural leader or functional leader. The position of a leader in every kind of public sector organization is closely related to its performance (Sotarauta, 2007). This statement is not a new perspective since many people in the past believed in the strong relationship between a leader's capacity and organization performance. It has also become the trigger for literature development about leadership in the public sector, which has consequently developed multiple theories from various angles.

Crossan (2017) offers 11 essential characters covering appropriate and effective leadership comprising courage, accountability, justice, temperance, integrity, humility, humanity, collaboration, drive, and transcendence. While other perspectives stayed with the simple approach, such as Rivani (2016) who describes five principles of leadership in relation with implementing good governance: vision, unifier, communication, emotion-ratio, and integrity. Siagian (2000) contributes by defining the quality of public sector leadership that should cover these aspects: vision, control of relationships within the organization, spirit of the organization, and information delivery. This paper uses the leadership attributes that are suitable for a good governance context at local government level in Indonesia. This means that the simple approaches such as Rivani (2016), Siagian (2000), and Bennis \& Nanus (1985) will be more applicable than Crossan (2017) or Raffo (2013) which provide more complex analysis through multiple dimensions. The more complex analysis covers many aspects, some of which are difficult to identify in Lamandau city as it is still a relatively new autonomous region.

\section{Good Governance from a local autonomous}

\section{perspective in Indonesia}

There is a long story about Indonesian experience regarding the implementation of decentralization and local autonomy. The first notion about decentralization in Indonesia was actually noted in Law No. 5 in 1974 which mentions the administration of local government in Indonesia (Hermawan, 2014). On this occasion, the discussion about decentralization was limited to administrative functions brought from central to local government. The position of local government however was merely an extension of central government, as there was no share authority nor autonomy until 1998 when Soeharto's regime met its downfall.

It has been nearly two decades since the end of Soeharto's regime (in 1998) and the start of decentralizing the authorities and functions of central government. The decentralization and local autonomy policy was outlined under Law No. 22/1999 about local government and Law No. 25/1999 concerning the fiscal 
balance between central and local government. There are many arguments stating different reasons behind the creation of these laws, including the failure of central government to deal with the economic crisis in 1997, the huge demand of democracy against the absolute position of central government, and the massive corruption or other political issues that were becoming common headlines in the Indonesian media at that time (Beerkens, 2000). Beside all of these reasons, the national statistic agency of Indonesia (BPS) noted one important explanation underpinning this whole phenomenon was inequality from the central government who had over 203 million people living in millions of square kilometers (BPS, 2001). It seems difficult to neglect that the conception of decentralization is needed by a huge archipelago country like Indonesia.

The notion of a good governance concept in Indonesia invoked governmental discussion aligning the implementation of decentralization and local autonomy. Widodo (2001) argued that "in order to provide better service for society, the government needs to get closer to them". This means that either decentralization or local autonomy has to open the gate for a good governance conception to penetrate the public environment in Indonesia. However, there are plenty of conversations about good governance patterns with different principles, indicators, focuses or even elements, for instance. Three main principles of good governance consisted of transparency, participation, and accountability (Bevir, 2002). The conference of human rights held by the UN conveyed five key components of good governance: transparency, responsibility, accountability, participation, and responsiveness. Furthermore, Wasistiono (2003) stated that the basic principles to measure good governance are accountability, responsibility, transparency and fairness. Consequently, the implementation of good governance in Indonesia was not clear for first-five years after the Soeharto regime's downfall (Purnaweni, 2004). Law No. 33 in 2004 appeared to answer all of the problems associated with the implementation of good governance in Indonesia.

Law No. 33 provides set of explanations regarding assets, authority and limitation for autonomous regions in Indonesia (Batubara, 2012). It explains two main interests, comprised of central government interest and those of local government. The share of interest between central and local government will accelerate the regional development by maximizing local creativity (Mardiasmo, 2002). In addition, the local government interest should be allocated following three main principles including local accountability, political welfare, and local responsiveness (Agus, 2011). Moving from this conversation, this paper uses the basic principles of good governance as conveyed by Wasistiono (2003) as variables of good governance. This was chosen due to its suitability with the three principles from the allocation of local government interests, as noted in Law No. 33 in 2004. Furthermore, the Indonesian Institute of Corporate Governance (IICG) published similar indicators of good governance: 1) Transparency, 2) Accountability, 3) Independency, 4) Responsibility, and 5) Fairness. This study merges the transparency and accountability indicator into one variable of good governance since both can be combined into a single hypothesis. The other three indicators will therefore become the pure variables of good governance without any modifications. 


\section{Case study and methodology}

\section{Case study overview}

Lamandau city was chosen for the case study due to its suitability in explaining the influence of leadership, which was due to two main reasons. First, Lamandau is a new autonomous region, positioned on the platform of the Indonesian decentralization concept since 4 August, 2002. In other words strong leadership skills were required to support good governance, particularly in the early years once Lamandau was declared as an autonomous region. Aside from this, the new autonomous region will enable researchers to avoid asymmetric programs and the leader's performance ${ }^{1}$. The second reason is that most of governmental cabinet in Lamandau has plenty of experience in terms of their strategic position in local government in Lamandau. The local mayor of Lamandau, for example, has been elected twice in local elections. Although all of this does not guarantee that the best information is gathered in line with this research, it can be expected to increase the criteria of accuration due to the better perception of Lamandau society toward their leader.

Lamandau is a new autonomous region located at latitude 1'9-3'36 South and longitude 110'25-112'50 East. It is one of the cities emerging from the bifurcation of Kotawaringin city in the West Kalimantan province of Indonesia. It serves eight administrative districts comprised of Bulik, Delang, Lamandau, East Bulik, Belantikan Raya, Menthobi Raya, Sematu Jaya, and Batangkawa. Each district consists of between nine and thirteen villages. Most of the inhabitants living in Lamandau are educated people: $10 \%$ graduated as bachelor or higher, $42 \%$ graduated or are currently in senior high school, $31 \%$ in Junior high school and $12 \%$ are at elementary school (Education Directory of Lamandau, 2015). It can be inferred that only $2 \%$ of them are not educated. In addition, it also describes the education quality of the survey sample ${ }^{2}$. The preliminary study conducted in some communities as a sample indicated Lamandau society having a good knowledge of their government as leader. Only $2 \%$ of them failed to explain or recognize their government in so far as not recognizing their local mayor or other government officials.

\section{Methodology}

A quantitative approach was undertaken by this study to examine a set of hypothesis regarding the influence of leadership toward good governance in Lamandau city. In line with this quantitative approach, a set of questionnaires was prepared to collect the data and distributed around civilians in Lamandau selected through the process of stratified cluster sampling design. The size of the sample was determined by estimating the parameter of the population in Lamandau city. Table 1 shows the clear proportions of the population in Lamandau city according to each district, therefore the size of sample can also be measured through this table by using Slovin formula.

\footnotetext{
1 Some leaders may find that a great program finishes during his tenure, although the program was originating through the ideas of his predecessor. It is sometimes confusing to measure the performance of a leader in public sector under this circumstance.

2 It refers to the society's education in Lamandau ranging from elementary school to bachelor degree which is indirectly showing the capability of respondent to understand the question in the research.
} 
Table 1

\begin{tabular}{|c|l|c|c|c|}
\hline No & \multicolumn{1}{|c|}{ District } & Population (N) & Percentage, $\%$ & Sampling size (n) \\
\hline 1 & Bulik & 24.381 & 34 & 135 \\
\hline 2 & Bulik Timur & 9.663 & 13 & 52 \\
\hline 3 & Sematu Jaya & 9.960 & 14 & 56 \\
\hline 4 & Menthobi Raya & 7.171 & 11 & 43 \\
\hline 5 & Lamandau & 5.838 & 9 & 36 \\
\hline 6 & Belantikan Raya & 4.625 & 7 & 28 \\
\hline 7 & Delang & 5.395 & 8 & 32 \\
\hline 8 & Batang Kawa & 2.667 & 4 & 398 \\
\hline & $\sum$ & 69.700 & 100 & 36 \\
\hline
\end{tabular}

The calculation of the Slovin formula as shown in following calculation indicates the minimum number of samples required to cover the survey in Lamandau city.

$$
n=\frac{N}{1+n e^{2}}=\frac{69700}{1+69700 \cdot(0,05)^{2}}=398 \text { Samples }
$$

In order to get a clear measurement of leadership influence toward good governance, this research divides the variables following the attributes of both concepts - leadership as well as good governance. It comprised leadership with strong vision (X1), leadership with good communication skills (X2), public trust for collective purpose (X3), and leadership with good individual capacity (X4) toward Transparency (Y1), Accountability (Y2), Independency (Y3), and Justice (Y4).

This research uses the deferential Thurstone scale due to its compatibility with parametric analysis (Kotari, 2004). This scale measures the interval ranging from 1 to 7 that is incorporated into the questionnaire design. It explains that 1 is the minimum while 7 is the maximum point of leadership attributes influence toward good governance variables. All of the data from this inquiry is processed through SPSS and take the Pearson product movement correlation to measure every single item and variable on this inquiry and decide its validity.

\section{Findings}

This section elaborates on the result of the inquiry undertaken during field research in Lamandau city, central Kalimantan province, Indonesia. In this research we found clear evidence of society's exposure related to a leadership aspect in the Lamandau government. Most of the samples living in Lamandau city were able to describe the main characteristics of Lamandau government, especially the mayor who has been elected twice in local elections. Therefore, the researchers 
had no particular difficulties in collecting any of the information in order to fulfill the relevant question regarding research variables, sub-variables and research indicator. Overall, the findings of this inquiry indicate a positive influence between leadership variables toward good governance variables. The findings show there are strong influences between a leader's vision on good governance in terms of transparency $(\mathrm{X} 1 \rightarrow \mathrm{Y} 1)$. Through some further questions, most of the respondents argue that "people put their trust in the Lamandau government because of their visions and the way we see it shows how transparent the government is". The p-value indicates 0,002 which is smaller than the alpha $(\alpha=0,05)$ and prove that both of these variables have an influence.

Moving on to other variables, the communication indicates a similar result to the previous response when examined toward accountability (X2 $\rightarrow \mathrm{Y} 2)$ by the $p$-value of $0,0001<\alpha=0,05$. It measures society's perspective related to government capability to communicate policy execution with society. In his book, Bevir (2007) noted "the communication is one essential aspect needed to deliver policy execution, especially in accountability". At this point, the communication does not merely refer to the way the government communicates literally, but rather emphasizes how the government implements effective communication, so that they can maximize coordination among public institutions and accountability for society at the same time. In the Lamandau context, most of the samples describe well society's understanding toward the vision, programs, and future plans of the government. Furthermore, some of the samples indicated their active participation within the Lamandau government forum. Perhaps this is one effective way of finding a viable solution for any problem associated with policy implementation.

The next variables reveal collective purposes toward independency $(\mathrm{X} 3 \rightarrow \mathrm{Y} 3)$ resulting in $p$-value of $0,028<\alpha=0,05$. It explains the public trust of Lamandau society toward in their local government in terms of policy, programs, and decisions. Although the extended questions reveal some doubts when dealing with the decision on independence. In chronological order the answers of respondents resulted in a conical shape, which means there are a wide range of answers to the early questions but pointed in same direction at the end. Most of the respondents give various interpretations to express their trust of the local government. However at the end they were mostly in agreement that the, policy, programs and decisions will be aimed towards development. These extended questions contributed to shaping the accuracy of the answers since most of the respondents had limited knowledge of either the collective purposes of government or the independency aspect.

The last variables also indicates the positive influence between the individual capacity of a leader toward good governance in terms of justice $(\mathrm{X} 4 \rightarrow \mathrm{Y} 4)$ for Lamandau society with a $p$-value of $0,001<\alpha=0,05$. It is true that if we are pairing the individual capacity of a leader toward the justice for society without any rationales, it will consequently lead to a blurred interpretation since the context of justice can be observed from multiple perspectives. One notable case portraying this assertion is the US immigration reform case of 2008, brought in by Barack Obama, which expressed an inverted correlation between leadership capacity and 
justice for society (Middleton, 2014). Therefore, this research pairs the individual capacity with justice as one good governance attribute. It explains the context of this variable which is closer to the principle of equity or social justice. Beside the good governance attributes, one of the most important considerations to involve this variable is its relevance with PANCASILA as the philosophical foundation of the Indonesian governing system.

According to the result of this inquiry, all of the variables aligned positive coefficient with various values, as seen in Table 2 below.

Table 2

\begin{tabular}{|c|c|c|c|c|}
\hline No & Line & Coefficient & t-value & p-value \\
\hline 1 & $\mathrm{X} 1 \rightarrow \mathrm{Y} 1$ & 0,164 & 3,141 & 0,002 \\
\hline 2 & $\mathrm{X} 2 \rightarrow \mathrm{Y} 2$ & 0,217 & 4,070 & $<0,001$ \\
\hline 3 & $\mathrm{X} 3 \rightarrow \mathrm{Y} 3$ & 0,142 & 3,255 & 0,028 \\
\hline 4 & $\mathrm{X} 4 \rightarrow \mathrm{Y} 4$ & 0,222 & 4,436 & $<0,001$ \\
\hline
\end{tabular}

Source: Output IBM SPSS AMOS 22 (2017).

The positive coefficients explain linear correlation among examined variables.

\section{Discussion}

Assessing the leadership influence toward implementing good governance in a new autonomous region.

This discussion will be bordered by the grounded theory of leadership and good governance as well as the context of a new autonomous region without neglecting some reviews in an Indonesian context. We argue that it is impossible to take all of the three theoretical concepts above without considering the interference of the political environment such as the local government context, Indonesian law and regulations as well as local culture. According to all the findings of this research, it has been proven that there is an influence of leadership toward implementing good governance in a new autonomous region. However, the analysis process in this study shows different values, indicating various degrees of influence among variables. The following discussion is aimed at peeling back the deeply correlated historical context of these attributes as well as the legal basis of local government in Indonesia.

In assessing the leadership influence toward good governance in an autonomous region, it is difficult to separate it from the historical context of the local government's existence in Indonesia because the change in the legal basis of such as decrees or laws will significantly affect the local government performance in some ways (Irawan, 2017). Additionally, the legal basis also becomes a determinant factor sustaining both public sector leadership and good governance implementation. Figure 1, below, describes the chronological order of the local government leadership influence, the structural change, and the legal basis supporting the implementation in Indonesia. It also explains the correlation be- 
tween the evolution of those concepts' implementation with the variables examined in this inquiry.

The main information described by Figure 1 is on public sector leadership or good governance implementation of Indonesia, both of which have changed over more than a half century. This alteration was guided by democratic principles rooted in the indonesian constitution and at the same time it was released from the strong domination of an authoritarian scheme which was widely implemented during the colonization era (Hermawan, 2014).

The hundreds of years of colonization in Indonesia has cultivated a patron client $^{3}$ relationship within Indonesian governmental structure especially for the leader and his subordinates (Hermawan, 2014); the relationship between central and local government is no exception. Under these circumstances, the discussion about vision and purposes in local government no longer exists because the central government has dominant control toward local government, as noted in Indonesian Constitution of 1945 (Irawan, 2017). The control of central government creates a settled trajectory for the local government to deliver the national policy at a local level. Thus, the capacity and communication of local government developed better than the vision and collective purposes because the latter two attributes belong to central government.

\section{Evolution of local government leadership, structural change and legal basis of decentralization in Indonesia}

\begin{tabular}{|c|c|c|c|c|c|}
\hline $\begin{array}{l}\text { Denotes } \\
\text { to leadership } \\
\text { influence } \\
\text { in local } \\
\text { government } \\
\text { perspective } \\
\text { (Variable } \\
\text { X1-X4) }\end{array}$ & $\begin{array}{l}\text { Administrative } \\
\text { Function } \\
\text { Commu- } \\
\text { nication } \\
\text { Capacity }\end{array}$ & $\begin{array}{l}\text { Administrative } \\
\text { function } \\
\\
\text { Commu- } \\
\text { nication } \\
\text { Capacity }\end{array}$ & $\begin{array}{l}\text { Semi-Political } \\
\text { Function } \\
\text { Communication } \\
\text { - Vision } \\
\text { Capacity }\end{array}$ & $\begin{array}{l}\text { Political function } \\
\text { - Communication } \\
\text { - Vision } \\
\text { - Capacity } \\
\text { - Collective } \\
\text { purposes }\end{array}$ & $\begin{array}{l}\text { Political function } \\
\\
\text { - Communication } \\
\text { - Vision } \\
\text { Capacity } \\
\text { - Collective } \\
\text { purposes }\end{array}$ \\
\hline $\begin{array}{l}\text { Structural } \\
\text { change } \\
\text { to implement } \\
\text { good } \\
\text { governance } \\
\text { (Variable } \\
\text { Y1-Y4) }\end{array}$ & $\begin{array}{l}\text { Centralization } \\
--\end{array}$ & $\begin{array}{l}\text { Administrative } \\
\text { decentraliza- } \\
\text { tion (Decon- } \\
\text { centration) } \\
-\end{array}$ & $\begin{array}{l}\text { Decentralization } \\
\text { and Financial } \\
\text { balance } \\
\text { Transparency } \\
\text { Accountability }\end{array}$ & $\begin{array}{l}\text { Decentralization } \\
\text { and Local } \\
\text { Autonomy } \\
\text { (Devolution) } \\
\text { - Accountability } \\
\text { - Transparency } \\
\text { - Independency }\end{array}$ & $\begin{array}{l}\text { Decentralization } \\
\text { and Local } \\
\text { Autonomy } \\
\text { (Devolution) } \\
\text { - Accountability } \\
\text { - Transparency } \\
\text { - Independency } \\
\text { - Justice }\end{array}$ \\
\hline Legal Basis & $\begin{array}{l}\text { Constitution } \\
1945\end{array}$ & $\begin{array}{l}\text { Decree } \\
\text { No. } 5 / 1974\end{array}$ & $\begin{array}{l}\text { Decree } \\
\text { No. } 22 / 1999 \\
\text { Decree } \\
\text { No. } 25 / 1999\end{array}$ & $\begin{array}{l}\text { Decree } \\
\text { No. 32/2004 } \\
\text { Decree } \\
\text { No. } 33 / 2004\end{array}$ & $\begin{array}{l}\text { Decree } \\
\text { No. 23/2014 }\end{array}$ \\
\hline
\end{tabular}

Source: Author made.

\footnotetext{
3 Patron client refers to the relationship between the authority, status, and influence of a small group of people toward a less powerful community. It shows the dominance of a small group against the larger so the control and dominance are possibly applied (Hall, 2008).
} 
A few decades later the shift in regime from the old order ${ }^{4}$ to the new order ${ }^{5}$ saw the emergence of significant change within the public sector in Indonesia (Hadi \& Kusuma, 2006). Law No. 5 in 1974 was initiated as the first law sustaining the transfer of administrative matters from central to local government, also known as administrative decentralization (Yuliani, 2004). At this point, the implementation of good governance was limited to the construction of rule and law. In addition, the main orientation of local government was not the public services but attempting to implement the command and order of central government. The top-down approach was strictly implemented by Seoharto's regime and consequently any good governance attributes are difficult to identify since the local government is merely the extension of central's hand. The chaotic situation caused by economic crises (1998) forced the Soeharto regime to its downfall and demanded good governance implementation. The emergence of Law No. 22 in 1999 about local government and Law No. 25 in 1999 about the fiscal balance between central and local government provided a viable solution for the overwhelming problems at that time.

The birth in 1999 of Law No. 22 in 1999 and Law No. 25 provided particular space for enabling the vision of local government leader to be developed. Both of these laws deal with two important issues of local government. On the one hand, Law No. 22 shared the authority of policymaking that previously belonged to central, and on the other hand, Law No. 25 shared similar authority in terms of budget. Therefore these laws are the first foundations of the political decentralization of local government leadership in Indonesia. Then it was possible for the local government leader to have such a vision for developing their own territory.

The transfer of some political authority from central to local enabled the local government to implement or at least adopt some good governance principles for public services. The notion of good governance principles such as participation was largely voiced through the media while both transparency and accountability were considered as good governance indicators although these were not the main course of good governance implementation at this time as the country underwent a period of resilience after the crises in order to restore economic, social and political stability. In 2004 the cabinets of the house of representative announced their discussion about local autonomy at local level and renewing Law No. 25 of 1999 to sustain this idea. The main reason why the local autonomous notion become increasingly voiced was because the administrative decentralization brought in by Law No. 22 of 1999 could not accommodate the effective decision making in some remote areas which were far away from the capital city where the central government exist. Therefore local autonomy was considered as one way to solve this problem. It can be inferred that the existence of Law No. 22 is no longer compatible with sustaining decentralization in Indonesia and ceased to function in the middle of 2004. The central government legitimized two laws - Law No. 32 in 2004 about local autonomy and Law No. 33 in 2004 which was about providing more appropriate finance for the implementation of local autonomous regions.

\footnotetext{
4 The old order refers to the regimes of President Soekarno (1945-1967).

5 The old order refers to the regimes of President Soeharto (1967-1998).
} 
The implementation period for Law No. 32 and Law No. 33 was 10 years. Many adjustments occured in this period, especially on the leadership aspect and good governance implementation. On the leadership side, the local autonomous framework has strengthened the relationship among local institutions including legislative and non-structural institutions at local level. It also explains that the local government may act independently in some circumstances ${ }^{6}$ through the collective decision making and consensus among these local actors. Good governance implementation under both Law No. 32 and Law No. 33 introduced a stable guidance to act independently from central government interference. The implementation of both Law No. 23 and Law No. 33 has successfully tightened society's behavior in getting used to the notion of good governance.

It is true that the implementation of Law No. 32 together with No. 33 has sustained positive implementation within all sectors of Institution in Indonesia but this does not mean that there are no critics at all. One critique aligning the implementation of Law No. 32 comes from the justice aspect, in so far as its real implementation is still questionable. The main reason as to why Law No. 32 seems to have difficulty covering the justice attributes is because it mainly talks about the general conception of local autonomy and administrative decentralization. In other words, the justice aspect has represented the normative value only rather than the actual context of implementation. Therefore, Law No. 23 of 2014 was legitimized in order to provide a backup to Law No. 32 of 2004.

Law No. 23 of 2014 is about a clear position, structure, relationship, authority, responsibility and guidelines for most institutions at local level. On this occasion, it is possible to identify the justice principle where the role of every actor is well decided. Law No. 23 brought in a stronger impact of justice regarding policy implementation at local level (Maturbongs, 2015). Thus, it can be concluded that the assessment of the influence of leadership toward the implementation of good governance has changed over time and the existence of supporting factors such as law, decree, and regulation is highly contributory to deciding whether it has a strong or weak influence. This also supports the statement by Raffo (2013) which examined the influence of effective leadership toward good governance implementation.

\section{Future projection of Lamandau's leader}

It is not an exaggeration if this paper uses the findings above and puts them together with the recent performance of Lamandau's local government, such as those noted in sets of policies or programs. Thus complete assessment can be illustrated in a more accurate way rather than relying on just the study result. This also enables the illustration of Lamandau's leader in the future.

In the early years since it was separated from Kota Waringin city, Lamandau city underwent a rapid transition in order to implement good governance and

\footnotetext{
6 The local government may set any policies and programs without intervention of central government, unless the program is included on one of these categories (education, military, religion, foreign relationship, health and sovereignty)
} 
perform the public sector leadership by following the local autonomous framework noted in Laws No. 32 and No. 33 of 2004. In line with its implementation, the local government of Lamandau created a strategic plan to transform the local vision toward the actual policy implementation by using a mid-term development plan called RPJMD (Rencana Pembangunan Jangka Menengah Daerah) and a long-term development plan called RPJPD (Rencana Pembangunan Jangka Panjang Daerah). Both of these strategic plans correlated with each other as the RPJMD is also part of the RPJPD that is implemented on the different timeframe. The RPJMD of Lamandau is about the mid-term development plan of Lamandau city in the 5 years ahead, while the RPJPD is mainly about the long term roadmap to achieving the long term goals of Lamandau city in the next 15 years and is mostly focused on clearing the path for RPJMD implementation. The contribution of the roadmap is represented by the leader's performance in the past, and the future plan of policy implementation. In addition, these will be aligned with the findings of the inquiry, so that some highlighted information such as 1) the changing of political environment, 2) the trend of public sector leadership, 3) the spectrum within the future projection of leadership, and 4) the future challenges can be illustrated.

In order to describe the future projection of leadership from Lamandau, it is firstly important to recognize the political environment of Lamandau that has changed over the time. The previous section has illustrated the change of political environment which tends to emphasize the concept of open government, which at the same time was bringing a democratic trend flowing through the framework of law, decree, and government regulation. The future leader will be asked to implement or at least adapt to these notions. Furthermore, the planned program of Lamandau as noted in RPJMD and RPJPD also has a similar orientation. Therefore, the future leader of Lamandau will be required to strengthen his vision and collective purposes since both of these attributes have gained less influence when compared to accountability and individual capacity.

The spectrum of leadership projection for Lamandau in the future is bordering on the criteria of leader that is needed by Lamandau city in the future. It is identified by using a combination of past experience including the major challenge of Lamandau associated with the rest of the program noted in RPJPD. So far, the result of this inquiry found that the major problem of Lamandau city is the lack of infrastructure development. It has to be admitted that the future leader of Lamandau should make this matter a priority, plus he is also required to have such a good capacity in social, environmental and economic calculations which are able to accommodate the infrastructure development since it is still the major challenge preventing better public service delivery. In a more detailed look, the future leader of Lamandau should be equipped with the appropriate capacity in terms of communication and coordination among implementing agencies in order to reduce the impact of these barriers. Completing this idea, the implementation of good governance should be strengthened and not limited to just local government bodies but also maximized in other bodies including the private sector and NGOs as the collaboration among them will return significant benefits in the future. 


\section{Conclusion}

The findings have proven that the influence of public sector leadership on the implementation of good governance can be interpreted by various degrees as a result of statistical analysis. Based on this study, it is expressed that the dominant influences of public sector leadership toward good governance in terms of communication toward accountability $(\mathrm{X} 2 \rightarrow \mathrm{Y} 2)$ and the influence of individual capacity toward justice $(\mathrm{X} 4 \rightarrow \mathrm{Y} 4)$ result in a similar value of 0,001 . The leader's vision toward transparency (X1 $\rightarrow \mathrm{Y} 1)$ comes out at 0,002 and is followed by collective purposes toward independency $(\mathrm{X} 3 \rightarrow \mathrm{Y} 3)$ at 0,028 . It can be inferred that the Lamandau local government has applied better performance to maintaining accountability and justice by maximizing communication and individual capacity. The rest of the variables reflect positive values, although less significant than the former, such as the influence of vision toward transparency as well as collective purposes toward independency. Although both of the latter variables come out with less significant values compared to the two former variables, they still indicate a positive influence. Some further questions conducted toward similar respondents regarding these values even still result in positive responses such as "people put their trust in Lamandau government because of their visions and the way we see describes how transparent the government is". Therefore, the researcher argues that there is particular tendency for respondents to fill the average value in the questionnaire, therefore the data of these variables indicates less significance.

These variables reflect an inverted correlation with the implementation on a legal basis in Indonesia. It has previously been mentioned that the implementation of good governance and public sector leadership was sustained by Law No. 5 in 1974; No. 22 and 25 in 1999; No. 32 and 33 in 2004; and No. 23 in 2014. The implementation of those laws allowed the development of both public sector leadership and good governance in Indonesia. In short, the variable of vision, capacity and communication has been implemented together with transparency and accountability which was supported by Law No. 22 and No. 25 in 1999. Then, followed by Independency and collective purposes five years later through Law No. 32 and 33 in 2004. Hence, justice became the last variable to be implemented, through Law No. 23 in 2014. However, the data from this study shows a contrary correlation because justice gives a more significant influence although implemented in a shorter period of time than the other variables which had been implemented over a longer period. Therefore, derived from this evaluation, the future leader of Lamandau needs to strengthen his vision and collective purposes in order to maintain transparency and independency.

\section{Acknowledgement}

We would like to thank Dr. Oscar Radyan Danar and Mr. Tommy Anggriawan who contributed and reviewed all versions of our manuscript.

We also would like to thank the editorial team and reviewer

for their comments and suggestions. 


\section{REFERENCES}

1. Agus, S. \& Ishak (2011). Political Budget of Riau Province: Case Study on the Controversy Within Zapin Monument Construction Iin Pekanbaru 2011 [Politik anggaran pemerintah provinsi Riau: Studi kasus pada kontroversi pembangunan tugu zapin kota Pekanbaru 2011]. Riau University.

2. Bale, T. (2015). If Opposition is an Art, is Ed Miliband an Artist? A Framework for Evaluating Leaders of the Opposition. Parliamentary Affairs, vol. 68, no 1, pp. 58-76.

3. Batubara, M.Y. (2012). The Existence of Law Number 32 of 2004 about Local Government [Eksistensi undang-undang nomor 32 tahun 2004 tentang pemerintahan daerah]. Journal of Pancasila's Education and Citizenship. State University of Malang.

4. Beerkens, E. (2000). The Student Movement and the Rise and Fall of Suharto. Available at: http://www.universityworldnews.com/filemgmt_data/files/ (accessed: 22 January 2018).

5. Bennis, W. \& Nanus, B. (1985). Leadership Strategies for Taking Charge. New York: Harper and Row.

6. Bevir, M. (2002). The Logic of History of Ideas. Cambridge University Press. UK.

7. Bevir, M. (2007). Encyclopedia of Governance. Sage Publication.

8. Birney, et al. (2010). Stepping up a Framework for Public Sector Leadership on Sustainability. Forum for the Future: Action for a Sustainable World. Available: Birney. steppinguppubsector-leadership.pdf (accessed: 04 October, 2018).

9. Boyne, G.A. (2002). Public Private Management: What is the Difference? Journal of management studies, vol. 39, no 1, pp. 97-122.

10. Burns, R.B. (2000). Introduction to Research Methods. 4th edition. French forest NSW. Longman.

11. Crossan, M.M., Byrne, A., Seijts, G.H., Reno, M., Monzani, L. \& Gandz, J. (2017). Toward a Framework of Leader Character in Organizations. Journal of Management Studies, vol. 54, no 7, pp. 986-1018.

12. Foley, M. (2008). The British Presidency. Manchester: Manchester University Press.

13. Fox, J. (2007). The Uncertain Relationship between Transparency and Accountability. Routledge publishing.

14. Frederickson, H.G., Smith, K.B., Larimer, C.W. \& Licari, M.J. (2012). The Public Administration Theory Primer. 2nd ed. Philadelphia: Westview Press.

15. Gardner, J.W. (1990). On Leadership. New York: The free press.

16. Gill, R. (2011). Theory and Practice of Leadership. 2nd ed. Sage Publication.

17. Giyanto, B. (n/d). Kewenangan Pejabat Publik Pengganti Dalam Pengambilan Keputusan Kebijakan Publik [The Authority of New Public Apparatus in Decision Making for Public Policy] (in Indonesian). Available at: https://media.neliti.com/media/publications/52388ID-kewenangan-pejabat-publik-pengganti-dala.pdf (accessed: 28 September, 2018).

18. Genovese, M.A. (1979). Democratic Theory and the Emergency Powers of the President. Presidential Studies Quarterly, vol. 9, no 3, pp. 283-289. 
19. Greenstein, F.I. (2009). The Presidential Difference: Leadership Style from FDR to Obama. Princeton University press.

20. Hadi, D.W. \& Kusuma, G. (2006). Propaganda Orde Baru 1966-1980 [New Order Propaganda 1966-1980] (in Indonesian). University of Airlangga. Available at: http://journal. unair.ac.id/download-fullpapers-4_jurnal\%20propaganda_dwiwahyonohadi.pdf (accessed: 18 February, 2018).

21. Hall, A. (2008). Patron Client Relations. The Journal of Peasant Studies, vol. 1, no 4.

22. Hay, C. (2002). Political Analysis. Basingstoke: Palgrave. Macmillan.

23. Hermawan, R. (2014). Coordination and Civil Service Reform (1999-2004). Center of South South cooperation studies. Bayumedia.

24. Hersey, P., et al. (1996). Management Organization Behavior: Utilizing Human Resources. Prentice hall, Upper Saddle Rivers. NY.

25. Irawan, D. (2017). Kajian Teoritis Terhadap Praktik Desentralisasi Dan Integrasi Politik Pasca Orde Baru [Theoretical Review of Decentralization and Integration after the New Order Era] (in Indonesian). Social and political science. National university, vol. 37, no 33, pp. 37833801. ISSN 0126-2602. Available at: http://repository.unas.ac.id/id/eprint/68 (accessed: 21 February, 2018).

26. Kaloh, J. (2010). Kepemimpinan Pemerintahan Daerah [The Leadership of Local Government] (in Indonesian). Jakarta.

27. Khan, A.R., \& Khandaker, S. (2016). Public and Private Organization: How they are Different or Similar are they. Journal of Humanity and Social Sciences, Siberian federal university, no 12 , vol. 9, pp. 2873-2885.

28. Körösényi, A., Illes, G. \& Metz, R. (2016). Contingency and Political Action: The Role of Leadership in Endogenously Created Crises. Journal of politics and governance, vol. 4, no 2, pp. 91-103. Doi: 10.17645.

29. Kotari, C.R. (2004). Research Methodology, Methods \& Techniques. New Age International Ltd. Publisher, India.

30. Lussier, R.N, \& Achua, C.F. (2007). Effective Leadership. Thomson Mass. South Western.

31. Mardiasmo (2002). Otonomi dan Manajemen keuangan daerah [Autonomy and Regional Finance Management] (in Indonesian). ANDI, Yogyakarta. Indonesia.

32. Marshment, J.L. (2016). Deliberative Political Leader: The Role of Policy Input in Political Leadership. Journal of Politic and Governance, vol. 4, no 2, pp. 25-35.

33. Maturbongs, E. (2015). Analisis Perubahan Pada Undang-Undang Nomor 32 Tahun 2004 Dengan Undang-Undang Nomor 23 Tahun 2014 Tentang Pemerintahan Daerah [The Analysis of Changing between Law Number 32 of 2004 and Law Number 23 of 2014 about Local Government] (in Indonesian). Available at:https://www.academia.edu/22966603/Analisis_ Perubahan_Pokok_Undang-Undang_Nomor_32_Tahun_2004_Dengan_Undang-Undang_ Nomor_23_Tahun_2014_Tentang_Pemerintahan_Daerah (accessed: 21 February, 2018).

34. Middleton, R.T. (2014). Comprehensive U.S. Immigration Reform: Policy Innovation and Non-Decisions. Seton Hall Legislative Journal, no 28, pp. 2.

35. Mitchell, S.M. (2002). Analyzing the Difference between Public and Private Sector Information Resources Management: Strategic Chief Information Officer Challenges and Critical Technologies. Thesis. Wright-Patterson Air Force Base, Ohio. 
36. Morgan, G. (1997). Images of Organizations. Thousand Oaks. CA: Sage Publication.

37. McGregor, D. (1960). The Human Side of Enterprise. New York. McGraw-Hill.

38. Northouse, P.G. (1997). Leadership: Theory and Practice. Thousand Oaks: SAGE.

39. OECD (2001). Public Sector Leadership for 21st Century. OECD Publishing. Paris. Available at: http://dx.doi.org/10.1787/9789264195035-en (accessed: 21 February, 2018).

40. Pramudji, S. (1985). Kerjasama Pemerintah Daerah Dalam Rangka Pembangunan Wilayah, Suatu Tinjauan Dari Administrasi Negara [The Cooperation Between Local Governments in Terms of Territorial Development Based on Public Administration Perspective] (in Indonesian). Institut Ilmu Pemerintahan, Jakarta.

41. Prasetiamartati, B. (2013). Policy and Participatory Local Governance in Indonesia: Programme Manager Decentralization and Local Governance. UNDP Indonesia.

42. Purnaweni, H. (2004). Demokrasi Indonesia: Dari masa ke masa [Democracy in Indonesia: from One Period to the Other] (in Indonesian). Public Administration Journal of Diponegoro University, vol. 3 , no 2 .

43. Rafflo, M.D. (2013). Qualities of Effective Leadership and Impact on Good Governance, Murfreesboro, TN, USA.

44. Smith, B. (2008). The Origins of Regional Autonomy in Indonesia: Experts and the Marketing of Political Interest. Journal of East Asian Studies, no 8, pp. 211-234.

45. Siagian, S.P. (2000). Teori pengembang organisasi [Organizational Development Theory]. Bumi Aksara. Jakarta.

46. Sotarauta, M. (2007). Leadership and Promotion of Regional Development: An Empirical Analysis of Power and Influence of Tactics in the Finnish Regional Development Activity. SENTE. Working paper 12/2007.

47. Steinberg, M.P. (2013). Leadership and Decentralized Control of School. Regional Education Laboratory: ICF International.

48. Stogdill, R.M. (1948). Personal Factors Associated with Leadership: A Survey of the Literature. Journal of Psychology, vol. 25, no 1, pp. 35-71.

49. Stone, A.G. \& Patterson, K. (n/d). The History of Leadership Focus. School of Leadership Studies. Regent University. Url:http://www.regent.edu/acad/sls/publications/conference_ proceedings/servant_leadership_roundtable/2005/pdf/stone_history.pdf

50. Tucker, R.C. (1968). The Theory of Charismatic Leadership. Daedalus, vol. 97, no 3, pp. 731-656.

51. Usman, S. (2002). Regional Autonomy in Indonesia: Field Experiences and Emerging Challenges. Indonesian Regional Science Association (IRCA).

52. Vondey, M. (2008). Follower- Focused Leadership: Effect of Follower Self-Concepts and Self-Determination on Organizational Citizenship Behaviour. Emerging Leadership Journey, vol. 1, no 1, pp. 52-21.

53. Van Wart, M. (2003). Public Sector Leadership Theory: An Assessment. Public Administration Review, vol. 63, no 2, pp. 214-228.

54. Widodo, J. (2001). Good Governance: Accountability and Bureaucratic Control in Decentralization Era and Regional Autonomy. Surabaya. Insan Cendekia. 
55. Wasistiono (2003). Kapita selekta manajemen pemerintahan daerah [Capita selecta and Regional Management]. Focus Media, Bandung. Indonesia.

56. Yankelovich, D. (1991). Coming to Public Judgement: Making Democracy Work in a Complex World. Syracuse University Press. New York.

57. Yuliani, E.L. (2004). Decentralization, Deconcentration and Devolution: What do They Mean? Interlaken workshop 27-30 April 2004. Switzerland.

\section{OFFICIAL DOCUMENTS}

1. Education directory of Lamandau (2015). Data kemendikbud kabupaten Lamandau 2015.

2. Local regulation of Lamandau number 1/ 2013: the change of Medium Term-Development Plan of Lamandau (2009-2013). Lamandau local government.

3. Local Regulation of Lamandau number 1/ 2009 about Long Term- Development Plan of Lamandau (2005-2025).

4. Local Regulation of Lamandau number 1/ 2014 about Medium Term-Development Plan of Lamandau (2013-2018).

5. Faculty of Administrative Science, University of Brawijaya (2012). The Satisfaction Index Of Lembata's Society, Nusa Tenggara Timur Province. The Cooperation between the Local Government of Lembata and Faculty of Administrative Science-University of Brawijaya. 